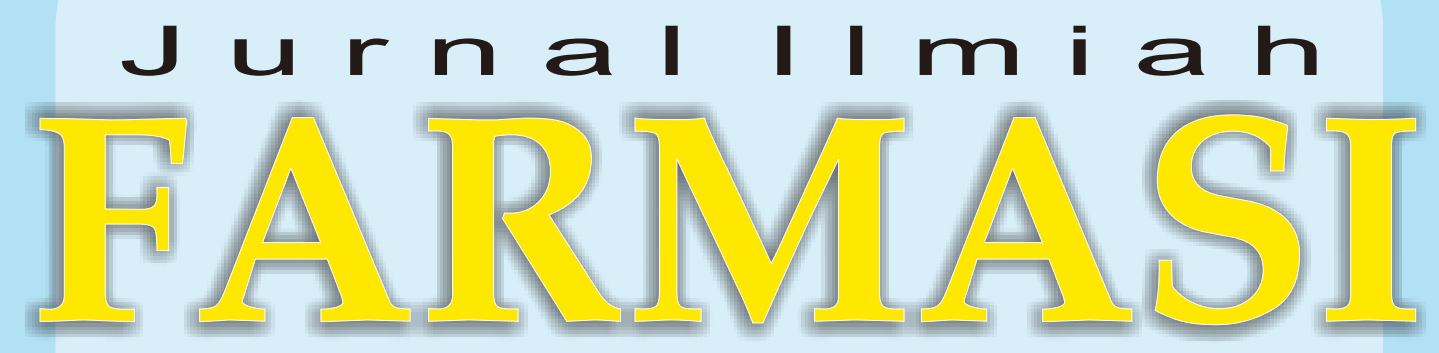

(Scientific Journal of Pharmacy) 
JURNAL ILMIAH FARMASI

(SCIENTIFIC JOURNAL OF PHARMACY)

PIMPINAN UMUM/ PENANGGUNG JAWAB

Dekan Fakultas Matematika dan Ilmu Pengetahuan Alam

Universitas Islam Indonesia

WAKIL PIMPINAN UMUM/ WAKIL PENANGGUNG JAWAB

Ketua Jurusan Farmasi FMIPA UII

\section{MITRA BESTARI}

1. Prof. Dr. Wiryatun Lestariana, Apt

2. Prof. Dr. Zullies Ikawati, Apt

3. Prof. Dr. Sudibyo Martono, Apt

4. Dr. Tedjo Yuwono, Apt

5. Prof. Dr. Dachriyanus, Apt

6. Prof. dr. Iwan Dwiprahasto, MMedSc, PhD

7. Prof. Dr. Lukman Hakim M.Sc., Apt

8. Prof. Dr. Achmad Fudholi, DEA, Apt

9. Prof. Dr. Ibnu Gholib Gandjar, DEA., Apt

\begin{tabular}{ll} 
& \multicolumn{1}{c}{ DEWAN EDITOR } \\
Ketua & : Saepudin, M.Si., Apt \\
Sekretaris & : Rochmy Istikharah, M.Sc., Apt. \\
Anggota & : Vitarani Dwi Ananda Ningrum, M.Si., Apt \\
& Okti R. Mafruhah, MSc., Apt \\
& Dimas Adhi Pradana, MSc., Apt. \\
& Fithria DA. Suryanegara, MSc., Apt. \\
& Ari Wibowo, S.Farm., Apt \\
& Arba Pramudita Ramadani, MSc., Apt. \\
& Oktavia Indrati, S.Farm., Apt.
\end{tabular}

Penerbit

Jurusan Farmasi Fakultas Matematika dan IImu Pengetahuan Alam Universitas Islam Indonesia

Alamat Penerbit Jurusan Farmasi FMIPA UII

Jl. Kaliurang Km. 14,4 Yogyakarta 55584

Telp. (0274) 896439 ext. 3047

Email: jif@uii.ac.id 


\title{
EVALUASI PENGGUNAAN ANTIBIOTIKA PROFILAKSIS DARI ASPEK KETEPATAN JENIS, WAKTU DAN DURASI PEMBERIAN PADA PASIEN INSTALASI BEDAH SENTRAL SEBUAH RUMAH SAKIT SWASTA DI YOGYAKARTA
}

\author{
Dimas Adhi Pradana*1, Iwan Dwiprahasto ${ }^{2}$, Satibi $^{3}$ \\ ${ }^{1}$ Fakultas MIPA, Jurusan Farmasi, Universitas Islam Indonesia, Yogyakarta \\ ${ }^{2}$ Fakultas Kedokteran, Universitas Gadjah Mada, Yogyakarta \\ ${ }^{3}$ Fakulats Farmasi, Universitas Gadjah Mada, Yogyakarta \\ *e-mail: adhi_pradana85@yahoo.com
}

\begin{abstract}
Surgical site infection is one of surgical infection that frequently happened in hospital so that the use of antibiotic prophylaxis must be safe. The research was conducted to know incidence of adverse event at usage of antibiotic prophylaxis in surgery installation. We use concordance sheet of antibiotic prophylaxis either from accuracy aspect of the drug type, administration time, duration of usage. Result analysis in the form of calculation relative risk of usage of antibiotic dissected pre prophylaxis to risk the happening of surgical site infections cases. Result this research show that relative risk value of usage of antibiotic to case of infection of operation hurt evaluated from inaccurate of type antibiotic 1,12 ( CI $95 \%: 0,138-9,1$ ), inaccurate aspect of gift time 5,8 ( Cl $95 \%: 1,024-32,86$ ) and from inaccurate aspect of duration of gift 3,21 ( Cl $95 \%: 1,043$ $9,9)$.
\end{abstract}

Keywords: antibiotic prophylaxis, surgical site infections, relatives risk 